International Journal of Business Management and Economic Review

Vol. 5, No. 01; 2022

ISSN: 2581-4664

\title{
THE EFFECT OF MOTIVATION AND PERCEPTION OF COMPENSATION FAIRNESS ON PERFORMANCE MEDIATED BY JOB SATISFACTION ON HOTEL EMPLOYEES IN BANDA ACEH
}

\author{
Rahmad, Hamdi Harmen and A.Sakir \\ Management Department, Universitas Syiah Kuala \\ http://doi.org/10.35409/IJBMER.2022.3358
}

\begin{abstract}
The purpose of this study was to examine the effect of motivation and compensation fairness on employee performance mediated by job satisfaction on hotel employees in city Banda Aceh. The population used in this study were all employees of 82 hotels in Banda Aceh, amounting to 170 people. Because the population was relatively small, the entire population was sampled. The sampling method used the census method. So the number of samples in this study was 170 respondents. Processing the data and analysis of research results used structural equation modeling (SEM). The results of the study prove that motivation affects job satisfaction, fairness of compensation does not affect job satisfaction, motivation affects employee performance, fairness of compensation affects employee performance, and job satisfaction affects employee performance. The variable with the greatest impact on this hotel employee performance model is employee satisfaction because it has the largest coefficient value compared to other variables. For the indirect hypotheses, the result shows that employee motivation affects employee performance mediated by hotel employees' job satisfaction and the fairness of compensation doesn't affect employee performance even though it is mediated by hotel employees' job satisfaction.
\end{abstract}

Keyword: Motivation, Compensation Fairness, Job Satisfaction, Employee Performance.

\section{INTRODUCTION}

Tourists will choose a hotel service if the hotel service can provide maximum satisfaction value for them or at least equal to the price they have spent. This encourages hotels to carry out various kinds of innovations and service modifications to get more consumers, with the hope of increasing profits, even though the current atmosphere is not conducive for the tourism industry due to the COVID-19 pandemic.

The city of Banda Aceh itself is a city that has many unique features where this city has many tourist attractions, especially the iconic Baiturrahman Grand Mosque and historical sites that are visited by many. Banda Aceh is one of the cities that was devastated by the Tsunami at the end of 2004, and made this city have many historical sites about the Tsunami, be it the Tsunami museum, the PLTD floating ship Punge Jurong and ships on the roofs of people's houses in Lampulo and make it a city which is visited by many tourists, which in the end many hospitality services have grown in this city.

The phenomenon that occurs is that hotels in Aceh, in general, experienced a very deep growth contraction even in the last five years only in 2016 and 2017 which grew positively, while 


\section{International Journal of Business Management and Economic Review}

Vol. 5, No. 01; 2022

ISSN: 2581-4664

the other three years were even negative, and the last two grew negatively, especially in 2018 which fell. very deep by minus 14.37 percent which at the same time nationally grew positively.

Table 1. Room Occupancy Rate (TPK)/Year

\begin{tabular}{|l|l|l|l|l|l|l|}
\hline No & Year & Aceh & Development & National & Development & Note. Aceh/National \\
\hline 1 & 2015 & $49.62 \%$ & $-0.64 \%$ & $57.25 \%$ & $-4.69 \%$ & Negative/Negative \\
\hline 2 & 2016 & $53.40 \%$ & $+3.78 \%$ & $56.50 \%$ & $-0.75 \%$ & Positive/Negative \\
\hline 3 & 2017 & $57.75 \%$ & $+4.35 \%$ & $59.53 \%$ & +3.03 & Positive/Positive \\
\hline 4 & 2018 & $43.38 \%$ & $-14.37 \%$ & $59.75 \%$ & +0.22 & Positive/Positive \\
\hline 5 & 2019 & $41.70 \%$ & $-1.68 \%$ & $59.39 \%$ & +0.36 & Negative/Positive \\
\hline
\end{tabular}

To improve hotel service to its guests, it must start from the employees, especially those who work on the frontline. In order for employee performance to increase, it must start from motivating employees. Each employee at a hotel has a different or different level of work motivation. Work motivation is very influential on the strength of the desires and needs (needs) of each employee. These wants and needs drive (push) them to achieve their goals (goals). When that goal has been fulfilled, a work spirit will grow from within them. Therefore, the behavior of employees at every hotel in Banda Aceh to achieve goals is very influential on motivation, and this motivation grows because they have desires and needs following what they expect. The closer to the expectations they want to achieve, the more satisfied they will be with the results they receive from their work (Hasibuan, 2016). The phenomenon of motivation at work is very important to the productivity of the company. Based on early observations with some hotel employees in some hotels, it was found that some phenomena of employee work motivation, among others, are that there are still employees who relax more than work. After that, there are still employees who prioritize individual interests over the workplace in carrying out their duties such as picking up their children to school while they are still in working hours, after that if there are errors in their work, employees still lack the initiative to fix them and there are still few employees in generating new ideas in completing tasks.

Not only motivation, but compensation is also a variable that also greatly influences employee performance either directly or through employee satisfaction (Robbins \& Judge, 2013). In addition, compensation fairness is also still happening and there are gaps between the organization and its employees, resulting in job satisfaction not being fully felt by employees, resulting in performance that is still not as expected by the organization. The phenomenon related to the compensation provided by the company is that there is still a lack of several facilities, such as an office at work, a vehicle, a place to live, as well as non-financial gifts such as vacations,

In addition to motivation and fairness of compensation, job satisfaction is also very important and becomes one of the important factors in achieving organizational goals. High job satisfaction is expected to improve the performance of hotel employees for the better. This can be seen from the feeling of happiness and ownership of hotel employees towards the survival of a hotel and in achieving its goals. The phenomenon related to job satisfaction that occurs in hotel employees in Banda Aceh can be seen from the feeling of happiness felt by employees, productivity that tends to decrease, and decreased work morale. 


\section{International Journal of Business Management and Economic Review}

Vol. 5, No. 01; 2022

ISSN: 2581-4664

The main problem in this study is the low performance of employees in the hospitality industry in Banda Aceh. One of the indications is that the declining hotel occupancy rate in Aceh continues to show negative growth, although nationally it is positive. In the last five years, only 2016 and 2017 grew positively, while the other three years were even negative, even in the last two years, especially in 2018 the decline was very large reaching $14.37 \%$ percent, even though at the same time the growth of the national average occupancy rate grew positively. respectively 0.22 percent and 0.36 percent.

The main objective of this study is to analyze the factors causing the low employee performance of the employees working in the hotel industry in Banda Aceh. However, the specific objective of this paper include is to analyze how the influence of motivation, perceptions of compensation fairness, and employee satisfaction on the performance of hotel employees in Banda Aceh.

\section{LITERATURE REVIEW Motivation}

For (Mangkunegara \& Octorend, 2015) Motivation is what moves people towards goals. On the other hand, McCormick in (Mangkunegara \& Octorend, 2015). (Hasibuan, 2016), said that motivation is a condition that supports human attitudes, to want to work actively and be eager to achieve maximum results. Thus, based on some of the theories above, the author can formulate that motivation is an impulse from within a person that causes, distributes, and supports human attitudes towards a certain goal.

Motivation is one of the major triggering aspects of low employee performance. Motivation is an impulse or will that causes someone to do something so that it focuses employees on their goals. This proves that motivation can strengthen or weaken employee performance. Individually, work motivation can be seen from efforts to increase their living needs and the organization. Work motivation is tried to see its effect on behavior and behavior at work. Giving this motivation can have a positive impact on the application of work for employees (Widiyanti \& Fitriani, 2017).

(Hasibuan, 2014) in (Lavinia, 2018) suggests that work loyalty or loyalty is one of the factors that is strongly influenced by employee satisfaction.

H1: Motivation affects job satisfaction.

H3: Motivation affects Employee Performance

\section{Compensation}

According to (Nurcahyo, 2015) said that "Compensation is everything that employees receive as remuneration for their work that is balanced with employee expectations to meet the need for satisfaction with achievements that have been achieved and in line with the company's strategic business objectives".

Bagi (Ariandi, 2018) Compensation is all rewards received by employees for the results of the employee's work in the organization. Compensation can be in the form of physical or nonphysical and must be calculated and given to employees according to the sacrifices that have been made to the organization/industry where he works.

Employees who are given their rights in the form of compensation that is perceived as fair, want to bring up job satisfaction behavior from the person concerned (Sihombing, Sidjabat, \& Gultom, 2015). The theory of fairness is the theory that people equate their input and work with 
the input and work of others, and then respond to eliminate infairness. The characteristic of the object of assumption in this research is that compensation given is appropriate and fair to affect employee performance (Lavinia, 2018).

H2: Compensation Fairness affects Job Satisfaction

H4: Compensation Fairness affects Performance

\section{Job satisfaction}

(Handoko, 2008) in (Soetrisno, 2016) stated that job satisfaction is a pleasant or unpleasant emotional state for employees who view their work. Job satisfaction reflects a person's feelings towards his job. This can be seen in the positive attitude of employees towards work and everything that is faced in the work environment.

This loyalty is in a person will arise if he is satisfied with what he gets from the company (Robbins \& Judge, 2017) Loyalty that makes employees will serve the company and feel part of a company where they work. With this loyalty to employees, it will make it easier for the company to increase productivity in the company.

H5: Satisfaction affects Employee Performance

\section{Employee Performance}

For (Soetrisno, 2016), performance is the result of employee work in terms of quality, quantity, working time, and cooperation to achieve the goals that have been proclaimed by the organization. For (Mangkunegara, 2013), performance is the result of work in quality and quantity achieved by an employee in carrying out his duties following the responsibilities given to him. For (Fahmi, 2017) performance is the result of a process that refers to and is measured over a certain period based on the terms or agreements that have been formalized.

\section{Research Framework}

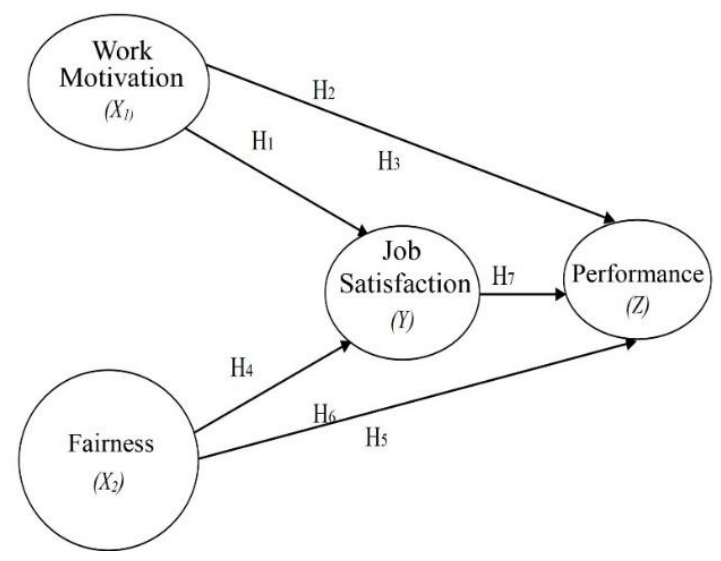

Figure 1. Framework of Research

To complete the analysis, the researcher will also examine the existence of the job satisfaction variable whether it can have a mediating effect on the model or not. Thus it will be added testing for indirect effects on this research model, namely:

H6: Motivation affects employee performance through job satisfaction 


\section{International Journal of Business Management and Economic Review}

Vol. 5, No. 01; 2022

ISSN: 2581-4664

H7: Fairness of compensation affects employee performance through job satisfaction.

\section{RESEARCH METHODS \\ Research Instruments}

All measurement items were taken from previous studies to ensure validity; however, slight changes to the statement were made to suit the current analysis. Five items of the Motivation questionnaire were adapted from (Mangkunegara, 2013). Seven items were adopted from (Wardiah, 2018). used to measure compensation fairness, while employee satisfaction is operationalized using the six indicator items proposed by (Wardiah, 2018). Then six items are used to measure employee performance which was adopted from (Robbins \& Judge, 2012).

\section{Sample Design and Data Collection}

The population used in this study were all employees of 82 hotels in Banda Aceh, amounting to 170 people. Because the population is relatively small, the entire population is sampled. The sampling method used the census method. So the number of samples in this study was 170 respondents. As for hotels and inns in Banda Aceh City, that is, as of 2019 data, there are 82 (eighty-two) lodging accommodation businesses, consisting of 1 (one) 5 (five) star hotel, 8 (eight) 3 (three) star hotels, 2 (two) 1 (one) star hotels, 57 (fifty-seven) budget hotels, 6 (six) other accommodation services, 1 (one) youth accommodation and 5 (five) tourist lodges

\section{Data analysis}

The data analysis technique in this research is descriptive and verification. Descriptive analysis was conducted to assess the demographic profile of the respondents and the internal consistency of construction. While the verification analysis uses SEM (Structural Equation Modeling) to verify the path of the relationship between tourist experience, destination image, and place attachment to environmentally responsible behavior. In addition, the SEM analysis software is IBM SPSS-AMOS.

\section{RESEARCH RESULTS AND DISCUSSION (DISCUSSION)}

Table 3. Characteristics of Respondents

\begin{tabular}{|l|l|l|l|}
\hline No. & Description & Percentage & Frequency \\
\hline \multirow{4}{*}{1.} & Gender : & & \\
\cline { 2 - 4 } & § Man & $65.9 \%$ & 112 \\
\cline { 2 - 4 } & § Woman & $34.1 \%$ & 58 \\
\hline \multirow{4}{*}{2.} & Respondent's age: & & \\
\cline { 2 - 4 } & $\S<20$ years & $19.4 \%$ & 33 \\
\cline { 2 - 4 } & $\S 21-30$ years old & $36.5 \%$ & 62 \\
\cline { 2 - 4 } & $\S 31-40$ years & $20.6 \%$ & 35 \\
\cline { 2 - 4 } & $\S 41-50$ years & $20 \%$ & 34 \\
\hline & $\S>50$ years & $3.5 \%$ & 6 \\
\hline \multirow{2}{*}{3.} & Marital status & & \\
\hline \multirow{2}{*}{} & & & \\
\hline
\end{tabular}




\section{International Journal of Business Management and Economic Review}

Vol. 5, No. 01; 2022

ISSN: 2581-4664

\begin{tabular}{|c|c|c|c|}
\hline No. & Description & Percentage & Frequency \\
\hline & $\S$ Married & $55.9 \%$ & 95 \\
\hline & $\S$ Not married yet & $44.1 \%$ & 75 \\
\hline \multirow{5}{*}{4.} & last education & & \\
\hline & § High School/Equivalent & $45.3 \%$ & 77 \\
\hline & $\S$ Diploma III & $4.7 \%$ & 8 \\
\hline & $\S$ Bachelor & $42.9 \%$ & 73 \\
\hline & $\S$ Postgraduate (S2 or S3) & $7.1 \%$ & 12 \\
\hline & Income & & \\
\hline & $\S<$ Rp. 2.000.000,- & $17.6 \%$ & 30 \\
\hline & § Rp. $2,000,000-2,999,999,-$ & $14.1 \%$ & 24 \\
\hline & § Rp. 3,000,000 - 3,999,999,-- & $9.4 \%$ & 16 \\
\hline & § Rp. 4,000,000 - 4,999,999,- & $42.9 \%$ & 73 \\
\hline & $\S>$ Rp. 5.000.000,- & $15.9 \%$ & 27 \\
\hline \multicolumn{2}{|c|}{ Amount } & $100 \%$ & 170 \\
\hline
\end{tabular}

In terms of age, most respondents came from the age group 21-30 years, namely 62 (36.5\%). From gender, there are more men than women, namely $112(65.9 \%)$. Then from the education group, the most educated are those who are educatedHigh school equivalent is 77 (45.3\%). In terms of income, the most are those with an income of IDR 4 million -5 million

Validity Measurement Model (Measurement Model)

Convergent validity aims to determine the validity of each relationship between the indicator and its latent construct or variable. In this study, a loading factor limit of 0.50 will be used. From the results of the measurement model calculations, 4 markers do not meet the requirements because they have a loading factor number below the required one, namely 0.5 . So the $\mathrm{m} 1$ marker is reliable. $\mathrm{m} 2, \mathrm{~m} 6$, and $\mathrm{m} 12$ must be eliminated. After elimination, the image of the new measurement model is:

Figure 2. Value of Loading Factor

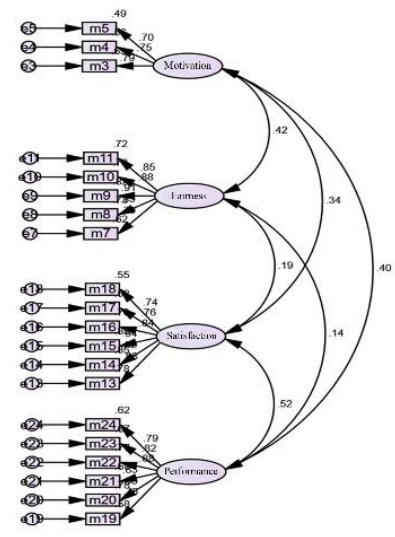

Table 3. Convergent Validity Results 
International Journal of Business Management and Economic Review

Vol. 5, No. 01; 2022

ISSN: 2581-4664

\begin{tabular}{|lll|l|}
\hline & & & Estimate \\
\hline $\mathrm{m} 3$ & $<---$ & Motivation & .793 \\
$\mathrm{~m} 4$ & $<---$ & Motivation & .745 \\
$\mathrm{~m} 5$ & $<---$ & Motivation & .700 \\
$\mathrm{~m} 7$ & $<---$ & Fairness & .786 \\
$\mathrm{~m} 8$ & $<---$ & Fairness & .852 \\
$\mathrm{~m} 9$ & $<---$ & Fairness & .907 \\
$\mathrm{~m} 10$ & $<---$ & Fairness & .882 \\
$\mathrm{~m} 11$ & $<---$ & Fairness & .850 \\
$\mathrm{~m} 13$ & $<---$ & Satisfaction & .882 \\
$\mathrm{~m} 14$ & $<---$ & Satisfaction & .924 \\
$\mathrm{~m} 15$ & $<---$ & Satisfaction & .943 \\
$\mathrm{~m} 16$ & $<---$ & Satisfaction & .836 \\
$\mathrm{~m} 17$ & $<---$ & Satisfaction & .763 \\
$\mathrm{~m} 18$ & $<---$ & Satisfaction & .738 \\
$\mathrm{~m} 19$ & $<---$ & Performance & .763 \\
$\mathrm{~m} 20$ & $<---$ & Performance & .882 \\
$\mathrm{~m} 21$ & $<---$ & Performance & .828 \\
$\mathrm{~m} 22$ & $<---$ & Performance & .877 \\
$\mathrm{~m} 23$ & $<---$ & Performance & .819 \\
$\mathrm{~m} 24$ & $<---$ & Performance & .790 \\
\hline
\end{tabular}

Source: AMOS Output Primary Data, 2021

After elimination, all indicators are said to be valid, because they have a loading factor number $>0.50$ so that all indicators in this research variable, namely Motivation, Perception of Compensation Fairness, Employee Satisfaction and Employee Performance are declared valid to be continued at the next research stage.

Reliability Test

The reliability test intended in this research is to identify the extent to which the measurement results are always statistically tested, namely by calculating the magnitude of the composite reliability of the information based on the estimated output obtained using Cronbach alpha. The results show that the instrument in this research is professional because its coefficient of reliability is greater than 0.60 (Malhotra, 2011).

Table 4. Variable Reliability Using Cronbach Alpha

\begin{tabular}{|l|l|l|l|l|}
\hline No & Variable & Cronbach Alpha & Items & Information \\
\hline $\mathbf{1}$ & Employee motivation & .732 & 5 & Reliable \\
\hline $\mathbf{2}$ & $\begin{array}{l}\text { Fairness of } \\
\text { compensation }\end{array}$ & .861 & 7 & Reliable \\
\hline
\end{tabular}




\section{International Journal of Business Management and Economic Review}

Vol. 5, No. 01; 2022

ISSN: 2581-4664

\begin{tabular}{|l|l|l|l|l|}
\hline \hline $\mathbf{3}$ & Job satisfaction & .941 & 6 & Reliable \\
\hline $\mathbf{4}$ & Employee performance & .927 & 6 & Reliable \\
\hline
\end{tabular}

Source: Primary Data 2021 (processed)

Motivation variable has a CA number of $73.2 \%$, Perception of Fairness of Compensation is $86.1 \%$, Employee Satisfaction is $94.1 \%$ and Employee Performance is $92.7 \%$. So the measurement of reliability on the research variables shows that the reliability measurement meets the requirements of Cronbach Alpha (CA) where the CA coefficient value is at least or greater than 60 percent.

\section{Verification of Hypothesis Testing}

Hypothesis test verification in this study was conducted to test and analyze the effect of switching cost, service quality, perceived value, satisfaction, and loyalty The verification hypothesis testing consists of testing the direct influence hypothesis and testing the indirect effect hypothesis. The results of testing the direct influence hypothesis can be seen in the following table::

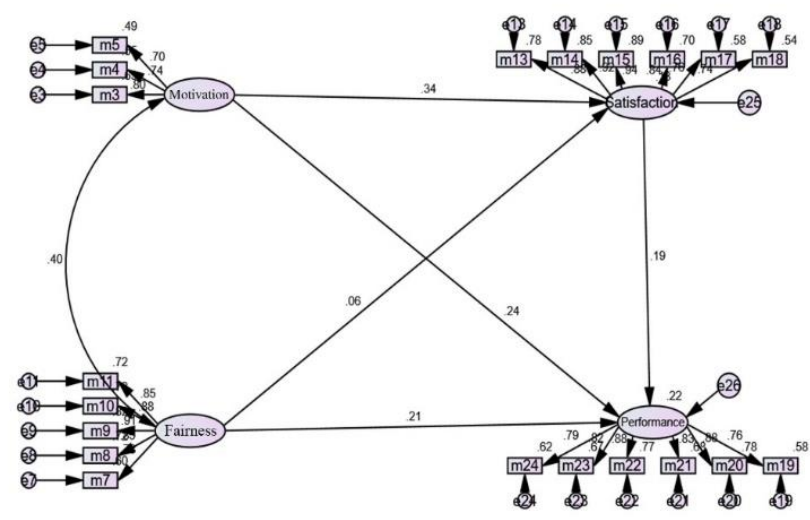

Figure 3. Structural Model

Table 5. Direct Effect Hypothesis Testing Results

\begin{tabular}{|l|l|l|l|l|l|l|l|}
\hline & & & Estimate & SE & CR & P & Beta \\
\hline Satisfaction & $<---$ & Motivation & .270 & .073 & 3.729 & $* * *$ & .335 \\
\hline Satisfaction & $<---$ & Fairness & .051 & .073 & .707 & .479 & .057 \\
\hline Performance & $<---$ & Satisfaction & .210 & .060 & 3.623 & $* * *$ & .187 \\
\hline Performance & $<---$ & Motivation & .223 & .083 & 2.681 & .007 & .244 \\
\hline Performance & $<---$ & Fairness & .212 & .059 & 3.625 & $* * *$ & .206 \\
\hline
\end{tabular}

Source: Primary data processed, 2021

H1: The effect of employee motivation on job satisfaction of hotel employees in Banda Aceh. 
International Journal of Business Management and Economic Review

Vol. 5, No. 01; 2022

ISSN: 2581-4664

This test shows a CR value of 3.729 and a P of ***. The magnitude of the coefficient of the influence of employee motivation on job satisfaction of hotel employees in Banda Aceh is 0.335 so that the impact of the influence of employee motivation on job satisfaction of hotel employees in Banda Aceh. by $33.5 \%$.

H2: The effect of employee motivation on the performance of hotel employees in Banda Aceh

Testing the influence of employee motivation on the performance of hotel employees in Banda Aceh shows a CR value of 2.681 and a probability of 0.007 . This means that if you want to increase the influence of employee motivation on the performance of hotel employees in Banda Aceh, work motivation must also be increased. The magnitude of the influence of employee motivation on the performance of hotel employees in Banda Aceh is 0.244 or $24.4 \%$. So that the influence of employee motivation can be used as one of the determinant factors to improve the performance of hotel employees in Banda Aceh

\section{H3: The effect of perceived fairness of compensation on job satisfaction of hotel employees in Banda Aceh.}

Testing the effect of perceived fairness of compensation on job satisfaction of hotel employees in Banda Aceh shows a CR value of .707 and a probability of 0.479. The magnitude of the coefficient of the effect of perceived fairness of compensation on job satisfaction of hotel employees in Banda Aceh. This is 0.057 or $5.7 \%$, a coefficient that is quite small so it has not been able to encourage an increase in hotel employee satisfaction in Banda Aceh.

\section{H4: The effect of perceived fairness of compensation on the performance of hotel employees in Banda Aceh.}

Testing the effect of perceived fairness of compensation on the performance of hotel employees in Banda Aceh shows a CR value of 3.625 and a $\mathrm{P}$ of ***. The magnitude of the coefficient of the effect of perceived fairness of compensation on the performance of hotel employees in Banda Aceh. is 0.206 or 20.6\%. Thus the impact it has on the effect of perceived fairness of compensation can be applied to improve the performance of hotel employees in Banda Aceh because of this significant effect.

\section{H5: The Effect of Employee Satisfaction on Employee Performance}

Testing the Effect of Employee Satisfaction on Employee Performance shows a CR value of 3.623 and a $\mathrm{P}$ of $* * *$. The magnitude of the coefficient of the influence of employee satisfaction on employee performance is 0.187 or $18.7 \%$. Thus the impact it has on the Effect of Employee Satisfaction on Employee Performance can be done because of this significant influence.

Even after testing, there were several rejected hypotheses, but most were accepted, including the two mediation hypotheses that were included in this study. Furthermore, judging from the magnitude of the coefficient number, the largest is Motivation which has an effect on Employee Performance with a score of 0.244 , a number that is quite dominant in a multivariate regression coefficient like this study. This means that the source of employee performance that arises is strongly influenced by how good the motivation of the employees is. The better the motivation of employees, it will have an impact on improving the performance of the employees themselves and have an impact on increasing organizational performance. 
International Journal of Business Management and Economic Review

Vol. 5, No. 01; 2022

ISSN: 2581-4664

\section{Serial Mediation Hypothesis Testing (Series Mediation)}

There are 2 (two) mediation hypotheses proven in this study, namely:

- The effect of employee motivation on employee performance mediated by hotel job satisfaction in Banda Aceh

- The effect of perceived fairness of compensation on employee performance mediated by job satisfaction in hotels in Banda Aceh.

The effect of employee motivation on employee performance mediated by hotel job satisfaction in Banda Aceh

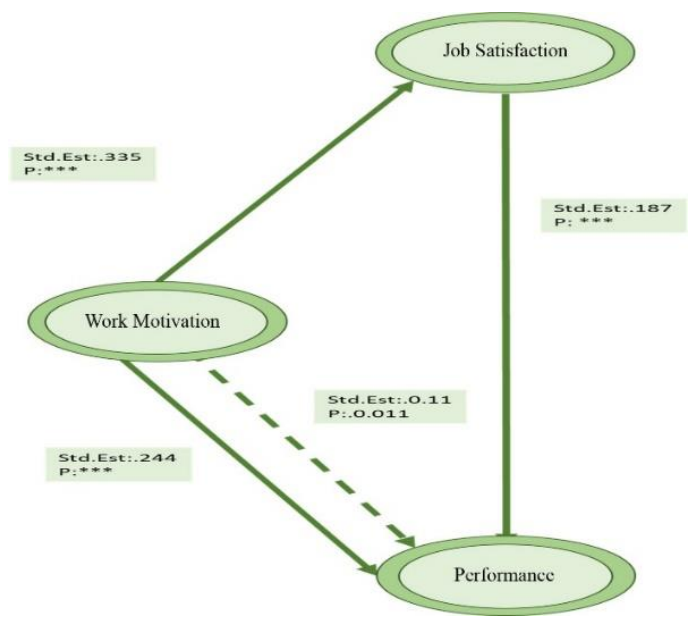

Figure 4. Employee motivation Affecting employee performance mediated by hotel job satisfaction in Banda Aceh

Based on the figure above, the estimated parameter values for testing the influence of employee motivation on performance mediated by hotel job satisfaction in Banda Aceh show a Pvalue of $* * *$. The $\mathrm{P}$-value obtained has met the requirements for acceptance of $\mathrm{Ha}$, which is less than 0.05. The magnitude of the coefficient of the influence of employee motivation on performance mediated by job satisfaction in hotels in Banda Aceh is 0.11 or $11 \%$. Thus, job satisfaction is said to be able to act as a mediating variable because the influence of employee motivation on performance mediated by job satisfaction in hotels in Banda Aceh is significant.

Because either directly or through employee satisfaction The effect of employee motivation on performance mediated by hotel job satisfaction in Banda Aceh is significant, employee satisfaction has a role as partial mediating.

The effect of perceived fairness of compensation on employee performance mediated by hotel job satisfaction in Banda Aceh 


\section{International Journal of Business Management and Economic Review}

Vol. 5, No. 01; 2022

ISSN: 2581-4664

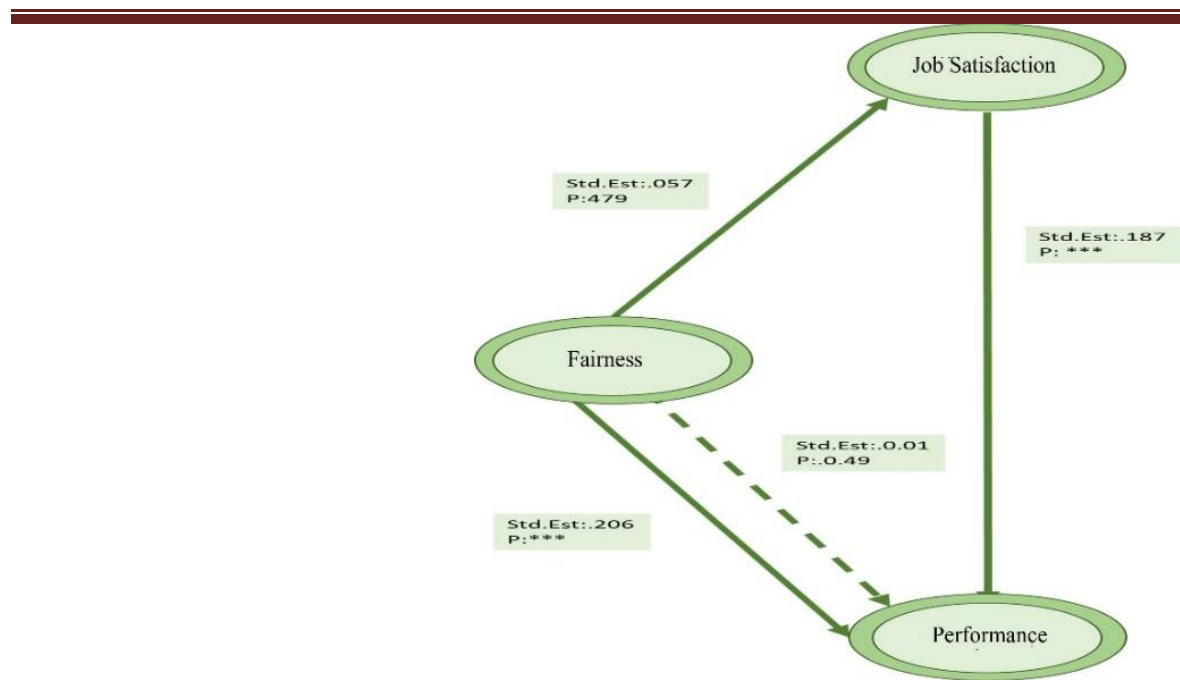

Figure 5. Perceived Fairness of Compensation Affecting Employee Performance mediated by Hotel Job Satisfaction in Banda Aceh

Based on the figure above, the estimated parameter values for testing the effect of perceived fairness of compensation on employee performance mediated by hotel job satisfaction in Banda Aceh show a P-value of 0.479. The magnitude of the coefficient of the effect of perceived fairness of compensation on employee performance mediated by hotel job satisfaction in Banda Aceh is 0.01 or $1.0 \%$. Thus, the effect of perceived fairness of compensation on employee performance mediated by hotel job satisfaction in Banda Aceh is proven to be insignificant.

Thus there is no mediation on the effect of perceived fairness of compensation on employee performance. In other words, job satisfaction does not function as a mediator on the effect of perceived fairness of compensation on the performance of hotel employees in Banda Aceh.

\section{CONCLUSION}

The results of the study prove that motivation affects job satisfaction, fairness of compensation does not affect job satisfaction, motivation affects employee performance, fairness of compensation affects employee performance, and job satisfaction affects employee performance. When asked which variable has the greatest impact on the formation of hotel employee performance in Banda Aceh, the answer is employee satisfaction, because it has the largest magnitude of influence compared to other variables such as employee motivation and perceptions of fairness of compensation. Thus, these findings provide ammunition for managers in the hotel industry in Banda Aceh city to improve the performance of their employees by increasing job satisfaction. The strategy to maintain job satisfaction that has been implemented so far needs to be improved because it has been proven that it has not been able to boost the overall performance of the employee.

Specifically for the indirect hypothesis of the two hypotheses tested, namely the effect of employee motivation on performance mediated by hotel job satisfaction in Banda Aceh and the effect of perceived fairness of compensation on performance mediated by hotel job satisfaction in Banda Aceh, it turns out that only one has a significant effect, namely The effect of employee 


\section{International Journal of Business Management and Economic Review}

Vol. 5, No. 01; 2022

ISSN: 2581-4664

motivation on performance mediated by job satisfaction in hotels in Banda Aceh. Therefore, the strategy of improving employee performance in the hotel industry in Banda Aceh should only be treated on the path of the influence of employee motivation on performance mediated by job satisfaction in hotels in Banda Aceh. The role of job satisfaction is as a partial mediating.

This finding indicates that the steps that must be taken by hotel managers to improve the performance of their employees are to increase employee job satisfaction. The aspect of feeling happy working in a hotel and the work environment that has been considered to hamper work productivity as indicated by the smallest mean number on the satisfaction variable should be the first priority for hotel managers to be improved. Likewise, the moral aspect has not increased due to the lack of appreciation given by superiors for the work performance that has been shown so far, it should also be improved.

\section{REFERENCES}

Ariandi, F. (2018). Pengaruh Metode Pembayaran Kompensasi Terhadap Kinerja Tutor. PERSPEKTIF: Jurnal Ekonomi \& Manajemen, 16(1), 84-90. https://doi.org/https://doi.org/10.31294/jp.v16i1.3106

Fahmi, I. (2017). Analisis Laporan Keuangan (6th ed.). Bandung: Alfabeta.

Handoko, H. (2008). Manajemen personalia dan Sumberdaya Manusia (2nd ed.). Yogyakarta: BPFE.

Hasibuan. (2014). Manajemen Sumber Daya Manusia. In Manajemen Sumber Daya Manusia (Revisi). Jakarta: Bumi Aksara.

Hasibuan, M. S. (2016). Buku Manajemen Sumber Daya Manusia (Revisi). Jakarta: Bumi Aksara.

Lavinia, D. (2018). Pengaruh Kompensasi Terhadap Loyalitas Karyawan Melalui Motivasi Kerja Sebagai Variabel Intervening Pada PT. Ehya Purwa Raharjo Gresik. AGORA, 6(1), 1-6.

Malhotra, N. K. (2011). Basic Marketing Research (4th ed.). London: Pearson.

Mangkunegara, A. P. (2013). Manajemen Sumber Daya Manusia Perusahaan. Bandung: Remaja Rosdakarya.

Mangkunegara, A. P., \& Octorend, T. R. (2015). Effect of Work Discipline, Work Motivation and Job Satisfaction on Employee Organizational Commitment in the Company (Case Study in PT. Dada Indonesia). Universal Journal of Management, 3(8), 318-328. https://doi.org/10.13189/ujm.2015.030803

Nurcahyo, R. J. (2015). Keterkaitan Visi, Misi Dan Values Terhadap Kinerja Karyawan Perusahaan Kulit "Dwi Jaya." Khasanah Ilmu, 6(2), 87-94. https://doi.org/https://doi.org/10.31294/khi.v6i2.476

Robbins, S. P., \& Judge, T. A. (2012). Organizational Behavior (15th ed.; S. Yagan, Ed.). San Diego: Pearson.

Robbins, S. P., \& Judge, T. A. (2013). Organizational Behavior 15th Edition. In The Curated Reference Collection in Neuroscience and Biobehavioral Psychology. https://doi.org/10.1016/B978-0-12-809324-5.06506-8 
International Journal of Business Management and Economic Review

Vol. 5, No. 01; 2022

ISSN: 2581-4664

Robbins, S. P., \& Judge, T. A. (2017). Essential of Organisational Behaviour (14th ed.). New Jersey: Pearson.

Sihombing, S., Sidjabat, S., \& Gultom, R. S. (2015). Manajemen Sumber Daya Manusia. Bogor: In Media.

Soetrisno, E. (2016). Manajemen Sumber Daya Manusia (Cetakan Ke). Jakarta: Prenada Media Gorup.

Wardiah. (2018). Pengaruh Kompensasi, Motivasi Dan Kepuasan Kerja Terhadap Kinerja Karyawan Pada PT. Dunia Barusa Banda Aceh. Universitas Syiah Kuala.

Widiyanti, W., \& Fitriani, D. (2017). Motivasi Kerja terhadap Kinerja Pegawai pada Dinas Kependudukan dan Pencatatan Sipil Kota Depok. Cakrawala, 17(2), 132-138. https://doi.org/https://doi.org/10.31294/jc.v17i2.2483 